\title{
Corrigendum to Vol. 4, Issue 2
}

Fuchs, R. \& Werner, V. (2018). "Tense and aspect in Second Language Acquisition and Learner Corpus Research: Introduction to the special issue". International Journal of Learner Corpus Research 4(2): 143-163. https://doi.org/10.1075/ijlcr.oooo4.int

Fuchs, R. \& Werner, V. (2018). “The use of stative progressives by school-age learners of English and the importance of the variable context. Myth vs. (corpus) reality". International Journal of Learner Corpus Research 4(2): 194-224.

https://doi.org/10.1075/ijlcr.17010.fuc

We would like to thank Prof. Kathleen Bardovi-Harlig for bringing two issues to our attention. The first one relates to an inaccurate reference. The actual source for Bardovi-Harlig (2012), cited on p. 148 and p.197, is Bardovi-Harlig, K. (2012). "Second language acquisition". In R. Binnick (Ed.), Handbook of Tense and Aspect. Oxford: Oxford University Press, 481-503. We further acknowledge that the abridged version of the Aspect Hypothesis (AH) presented on p.148 and p.197 (paraphrased from Bardovi-Harlig 2012: 484, who bases her list on Shirai \& Andersen 1996:533) may not be collectively endorsed. An arguably universally acceptable condensed version of the central generalizations of the $\mathrm{AH}$ is given below:

1. Learners tend to use the (perfective) past marking with telic verbs,

2. the imperfective past (in languages that have a perfective/imperfective distinction) with atelic verbs,

3. the progressive with activity verbs, and

4. do not overextend the progressive to stative verbs. (Yasuhiro Shirai, personal communication).

\section{References}

Andersen, R. W. \& Shirai, Y. 1996. "Primacy of aspect in first and second language acquisition: The pidgin/creole connection”. In W. C. Ritchie \& T. K. Bhatia (Eds.), Handbook of Second Language Acquisition. San Diego: Academic Press, 527-570.

Bardovi-Harlig, K. 2012. “Second language acquisition”. In R. Binnick (Ed.), Handbook of Tense and Aspect. Oxford: Oxford University Press, 481-503. 